\title{
SUMBANGAN KOSA KATA BAHASA SANSEKERTA TERHADAP PERKEMBANGAN BAHASA INDONESIA DAN JAWA BARU
}

\author{
oleh Hardiyanto dan Afendy Widayat \\ FBS Universitas Negeri Yogyakarta
}

\begin{abstract}
In their development, the languages referred to as Bahasa Indonesia (or BI, for short) and New Javanese (or NJ, for short) have absorbed a quantity of lexicon from Sanskrit. Much of the same lexicon has been absorbed from Sanskrit into BI and NJ. Granted that BI and NJ influence each other, perhaps BI has absorbed the Sanskrit lexicon from NJ or vice versa. However, referring to historical aspects, it is highly likely that the two have had access to Sanskrit from an old or ancient version of Javanese because Sanskrit has no longer been a living language since the $10^{\text {th }}$ century.

The process of the absorption of the Sanskrit lexicon into BI and NJ is divisible into at least three types: (1) without phonological, morphological, and semantic changes, (2) with phonological and semantic changes but without morphological changes, (3) with phonological changes but without morphological and semantic changes, The last-mentioned type is further divisible into at least five sub-types: (1) with a consonant shift, (2) with a long vowel changed into a short one, (3) with a double consonant changed into a single one, (4) with a phonological addition, and (5) with a phonological elimination.
\end{abstract}

Keywords: Sanskrit, Bahasa Indonesia, Javanese, lexical contribution

\section{A. PENDAhuluan}

Bahasa Sansekerta merupakan bahasa India Kuno. Bahasa ini menurut strukturnya termasuk tipe fleksi. Oleh karena itu, kata benda mengalami deklinasi, dan kata kerja mengalami konjugasi. Deklinasi kata benda ditentukan oleh jenis kata benda, huruf terakhir pada kata dasar kata benda, kasus kata benda, dan jumlah kata benda. Sedangkan konjugasi ditentukan oleh kelas urat kata kerja, kala kata kerja, arah kata kerja, dan persona.

Ada 3 jenis kata benda bahasa Sansekerta, yakni masculinum, neutrum dan feminum. Di samping jenisnya, perubahan kata benda juga ditentukan oleh huruf akhir pada kata dasarnya, baik vokal maupun konsonan. Kata dasar yang berakhir dengan vokal, terdapat sejumlah vokal, yakni -a, -â, -i, -î, -u, - û, -r, dan -diftong. Sedang yang berakhir konsonan, antara lain ditentukan oleh kata dasarnya asli kata benda atau kata turunan, ditentukan oleh satu atau dua suku kata, ditentukan oleh konsonan yang mengakhirinya. Dengan demikian yang perlu diketahui adalah kata dasarnya dan jenisnya untuk mengetahui tambahan yang terjadi hingga selanjutnya dapat dimengerti fungsinya (kasusnya) dan jumlahnya.

Sebagai contoh kata benda berakhir -a berjenis masculinum nara yang berarti 'orang', bila berada dalam kalimat, menduduki fungsi subyek (nominatif), dan 'orang' itu berjumlah satu (singularis) maka nara itu semestinya berubah menjadi naras. Hal ini berbeda bila nara itu jumlahnya dua (dualis) yang semestinya menjadi narâu (dua orang). 
Demikian pula bila berarti 'banyak orang' dalam fungsi subyek (nominatif) maka semestinya berubah menjadi narâs. Dalam bahasa Sansekerta ada 8 kasus, yakni nominatif (subyek), akusatif (obyek langsung), vokatif (seruan), datif (obyek tak langsung), ablatif (arah dari), genetif (milik), instrumentalis (alat), dan lokatif (tempat). Pada masingmasing kasus, setiap kata benda memiliki aturan perubahan atau tambahannya sendiri, misalnya nara yang berjumlah banyak (pluralis) dan berfungsi sebagai obyek langsung (akusatif), berubah menjadi narân .

Seperti disinggung di atas, sama-sama kata benda berakhir -a, deklinasi pada nara yang berjenis masculinum itu akan berbeda dengan deklinasi pada phala ':buah' yang berjenis neutrum. Dalam fungsi subyek (nominatif) phala yang berjumlah singularis menjadi phalam. Bila sebagai subyek dan berjumlah dua (dualis) menjadi phale dan bila banyak (pluralis) akan menjadi phalâni. Sedang dalam fungsi sebagai obyek langsung (akusatif), akan menjadi phalam 'satu buah', phale 'dua buah' dan phalâni 'banyak buah'.

Contoh deklinasi di atas akan berbedabeda lagi dengan yang terjadi pada deklinasi kata benda yang berakhir -i, -u, -â, -î, -û, dan seterusnya. Dengan uraian di atas kiranya menjadi jelas bahwa perubahan atau tambahan pada kata dasar kata benda (deklinasi) mengindikasikan fungsi kata itu dalam kalimat dan jumlah benda pada kata yang bersangkutan.

Dalam hal perubahan kata kerja (konjugasi), perubahan atau tambahan terjadi menurut personanya, jumlah personanya, jenisnya, modusnya, dan waktunya. Persona pertama, persona kedua, dan persona ketiga masing-masing dapat berjumlah singular (singularis), dualis, dan pluralis. Jenisnya ada tiga, yakni aktif (parasmâipadam), medium (âtmanepadam), dan pasif. Modusnya ada tiga, yakni indicatif, optatif, dan imperatif. Adapun waktunya ada lima, yakni presens, imperfectum, futurum, aoristus, dan perfectum. Hal lain yang juga berpengaruh pada konjugasi adalah dua golongan kata kerja, yakni golongan -a dan golongan bukan -a. Semua unsur tersebut di atas mempunyai aturan tambahannya atau perubahannya masing-masing dalam rangka proses konjugasi.

Sebagai contoh, urat kata kerja $j i$ 'menang' kata dasarnya menjadi jaya, konjugasi dalam presens indikatif aktif untuk persona pertama singularis (aku) berubah menjadi jayâmi, untuk persona kedua singularis (kamu) berubah menjadi jayasi, dan untuk persona ketiga singularis (ia) menjadi jayati. Perubahan itu akan berbeda lagi bila presens indikatif medium untuk persona pertama singularis (aku) berubah menjadi jaye, untuk persona kedua singularis (kamu) menjadi jayase, dan untuk persona ketiga singularis (ia) berubah menjadi jayate. Adapun bila dalam bentuk presens indikatif pasif, untuk persona pertama singularis (aku) berubah menjadi jiye, untuk persona kedua singularis (kamu) berubah menjadi jiyase, dan untuk persona ketiga singularis berubah menjadi jiyate. Konjugasi di atas akan berbeda perubahannya dengan konjugasi yang terjadi pada jumlah dualis dan jumlak pluralis pada setiap persona.

Di samping perubahan-perubahan yang terjadi akibat deklinasi dan konjugasi, dalam bahasa Sansekerta juga banyak terjadi perubahan bentuk dan bunyi pada berbagai kata yang merupakan akibat dari konvensi hukum bunyi bahasa Sansekerta. Sebagai contoh bunyi $s$ dan $r$ pada akhir kata yang berada pada akhir kalimat atau pada akhir kata yang berdiri sendiri, $s$ dan $r$ tersebut akan berubah menjadi visarga $h$. Demikian pula bila $s$ atau $r$ itu berada sebelum $k$, $k h, p$, $p h$, dan sebelum desis $c$, $s$, atau s. Untuk lebih jelasnya di bawah ini dicontohkan kalimat dalam bahasa Sansekerta beserta uraian dan terjemahannya, sebagai berikut.

\section{1). Dhanena sukhamicchanti narâh}

dhanena adalah kata benda, kata dasarnya dhana 'uang/ kekayaan', berjenis nuetrum, menjadi dhanena karena deklinasi instrumental (alat), singularis

sukhamiccanti dari kata sukham dan icchanti. 
sukham adalah kata benda, kata dasarnya sukha 'kebahagiaan' berjenis nuetrum, menjadi sukham karena deklinasi nominatif (subyek) / akusatif (obyek langsung), singularis

icchanti adalah kata kerja dari urat kata kerja is 'menginginkan', stemnya iccha, termasuk kelas -a, menjadi icchanti karena konjugasi indikatif presens, aktif, persona ketiga, pluralis. jumlah (pluralis) ini harus sesuai dengan jumlah kata benda yang menjadi subyeknya.

narâh adalah kata benda, kata dasarnya nara 'orang lelaki', berjenis masculinum, menjadi narâh karena dari narâs (berlaku hukum bunyi $s$ menjadi $h$ ) deklinasi nominatif (subyek), pluralis, jadi 'orang-orang lelaki'

jadi arti kalimat tersebut 'orang-orang lelaki menginginkan kebahagiaan dengan uang/ kekayaan'

\section{2). Kavayah sabhâyâm kâvyâpathan}

kavayah adalah kata benda, kata dasarnya kavi 'penyair', berjenis maskulin

kavayah dari kavayas (hukum bunyi $s$ menjadi $h$ ), menjadi kavayas karena deklinasi nominatif pluralis ('para penyair')

sabhâyâm adalah kata benda, kata dasarnya sabhâ 'majelis/ pertemuan', berjenis

feminum, menjadi sabhâyâm karena deklinasi lokatif (tempat), singularis

kâvyânyapathan dari kâvyâni dan apathan ( $i$ dan $a$ bersandi menjadi $y a$ )

kâvyâni adalah kata benda kata dasarnya kâvya 'syair', berjenis nuetrum menjadi kâvyâni karena deklinasi nominatif (subyek) / akusatif (obyek), pluralis

apathan adalah kata kerja dari urat kata kerja path 'membaca syair', menjadi apathan karena konjugasi imperfek aktif, persona ketiga, pluralis

Jadi arti kalimat di atas 'para penyair telah membaca syair-syair pada/ di pertemuan'

Dari uraian di atas kiranya menjadi jelas bahwa setiap kata dalam bahasa Sansekerta, sering kali berubah bentuknya dari bentuk dasarnya, karena mengalami deklinasi, konjugasi atau pun hukum bunyi yang berlaku.

Bahasa Sansekerta itu telah mati, yakni sejak abad ke-10 Masehi (Zoetmulder, 1983: 10) tetapi sebagian dari unsur-unsur kebahasaannya berperan terhadap perkembangan bahasa Indonesia dan Jawa Baru, yaitu sebagai donor kosa kata terhadap perkembangan bahasa Indonesia dan Jawa Baru.

\section{B. KONTAK BAHASA}

Setiap masyarakat pemakai suatu bahasa memiliki kesepakatan tentang bahasanya, misalnya berkaitan dengan kaidah atau struktur dan kosa kata. Kesepakatan kaidah dan kosa kata itu sampai batas waktu tertentu secara umum masih mampu mewadahi seluruh konsep, gagasan, dan ide para pemakainya. Namun, pada saat tertentu akan sampailah pada suatu kebutuhan akan adanya kesepakatan baru yang memperkaya dan melengkapi kesepakatan sebelumnya, yaitu manakala kesepakatan lama telah tidak cukup lagi mewadahi konsep, gagasan, dan ide yang ada.

Apabila telah sampai pada titik waktu seperti itu, maka masyarakat bahasa yang bersangkutan biasanya melirik kesepakatan masyarakat pemakai bahasa lain. Dengan demikian, maka terjadilah sebuah proses kreativitas masyarakat bahasa yang disebut pemungutan (borrowing) unsur bahasa terutama kosa kata dari bahasa lain (Saadie 1997/1998: 1). Dengan demikian pemungutan atau penyerapan menjadi salah satu penyebab terjadinya perkembangan suatu bahasa.

Proses terjadinya penyerapan itu sendiri tentu saja diawali oleh adanya kontak antarbahasa. Kontak antarbahasa terjadi karena adanya kontak antarmasyarakat bahasa. Jadi 
kontak bahasa terjadi dalam diri penutur secara individual. Individu-individu tempat terjadinya kontak bahasa disebut dwibahasawan .

Mackey dan (Suwito 1982: 34) memberikan pengertian kontak bahasa sebagai pengaruh bahasa yang satu kepada bahasa yang lain baik langsung maupun tak langsung, sehingga menimbulkan perubahan bahasa yang dimiliki ekabahasawan. Sedangkan kedwibahasaan diartikan sebagai pemakaian dua bahasa atau lebih oleh seseorang penutur. Ia memberi tekanan agar kontak bahasa dan kedwibahasaan tidak dikacaukan. Menurut pendapatnya kontak bahasa cenderung kepada gejala bahasa (langue), sedangkan kedwibahasaan lebih cenderung sebagai gejala tutur (parole). Karena langue pada hakikatnya adalah sumber dari parole, maka kontak bahasa sudah selayaknya nampak dalam dwibahasaan. Dengan kata lain, kedwibahasaan terjadi sebagai akibat adanya kontak bahasa. Kontak bahasa terjadi karena kontak antarbangsa, baik secara langsung maupun tidak.

Kontak antar bangsa tidak dapat dihindari. Tidak ada bangsa yang dapat membebaskan diri dari kontak dengan dunia luar. Hal ini menyebabkan tidak ada satu bangsa pun yang terbebas dari kontak dengan bahasa yang lain. Sebuah bahasa yang tidak kontak dengan bahasa lain lambat laun akan menjadi bahasa yang mati atau menjadi bahasa yang tidak ada penuturnya lagi. Oleh karena itu, bahasa Indonesia dan Jawa Baru dalam perkembangannya selalu terbuka untuk menerima kosa kata dari bahasa lain (termasuk kosa kata bahasa Sansekerta).

\section{SEJARAH PERKEMBANGAN BAHASA INDONESIA DAN JAWA BARU}

Sejarah perkembangan bahasa, antara bahasa Indonesia dengan bahasa Jawa Baru, dalam hubungannya dengan bahasa Sansekerta, pada dasarnya tidaklah jauh berbeda. Hal ini antara lain dikarenakan sejarah kebudayaan suka Jawa, tidak dapat dipisahkan sama sekali dari sejarah kebudayaan bangsa Indonesia. Suku Jawa merupakan salah satu suku yang dari segi historis maupun geografis menjadi pendukung yang signifikan terhadap eksistensi bangsa Indonesia.

Perkembangan bahasa Indonesia dan bahasa Jawa Baru, secara historis tidak dapat dilepaskan dari budaya bangsa Indonesia yang telah sejak semula mendapatkan pengaruh dari budaya dan agama Hindu dan Budha, suatu agama yang berkembang dari sekitar India Selatan. Kedua agama ini berkembang dengan banyak menggunakan bahasa Sansekerta. Bahasa Sansekerta merupakan bahasa resmi India, di samping bahasa Inggris, yang juga dipandang sebagai bahasa klasik dari kesusasteraan kuna India (Koentjaraningrat, 1993: 41). Ketika itu rupa-rupanya kebudayaan Hindu mempunyai kekuatan yang besar dan serupa dengan, misalnya, teknologi Barat di jaman modern ini. Kebudayaan intelektual dari agama Hindu mempengaruhi dunia Asia Tenggara jaman dulu (Koentjaraningrat, 1990: 21).

Hal lain yang perlu juga diperhatikan adalah kehidupan bahasa Indonesia yang beriringan dan sejaman dengan kehidupan bahasa daerah (baca: Jawa). Sebagian penutur bahasa Indonesia dan penutur bahasa Jawa Baru adalah pelaku kedwibahasaan, artinya menggunakan bahasa Indonesia sekaligus juga dengan bahasa Jawa Baru. Dengan demikian sangat dimungkinkan kedua bahasa itu saling menerima dan saling melengkapi. Hal yang demikian itu juga tidak mustahil terjadi pada kata-kata yang merupakan kata yang menyerap kosa kata dari bahasa Sansekerta.

\section{Sejarah Perkembangan Bahasa Indonesia}

Daerah-daerah melayu mulai sekitar abad ke-6, pernah tercatat sebagai daerah yang berkembang dalam pengaruh kerajaan Sriwijaya. Kerajaan ini berpusat di daerah pantai yang dimungkinkan berada di Palembang, atau di Jambi, atau di sekitar sungai Kampar di Sumatra Tengah. Kerajaan ini banyak mengembangkan agama dan kebudayaan Budha (Koentjaraningrat, 1990: 22-23). 
Bahasa Indonesia berkembang dengan induknya bahasa Melayu yang notabene banyak bergelut dengan agama dan budaya Budha, di samping agama dan budaya Hindu. Sumpah Pemuda pada tanggal 28 Oktober 1928 merupakan jaringan pernyataan kebulatan tekad yang dijalin oleh tiga buah unsur yang berkaitan erat dan memiliki hubungan timbal balik. Salah satu unsur yang penting merupakan pernyataan tekad bahwa yang disebut bahasa Indonesia adalah bahasa persatuan bangsa Indonesia dan ditetapkan pada kedudukan yang tinggi di dalam kehidupan nasional Indonesia (Halim 1986: 1).

Unsur Sumpah Pemuda, yang berupa pernyataan tekad " menjunjung bahasa persatuan, bahasa Indonesia”, pada dasarnya adalah pernyataan sikap kebahasaan. Sikap itu adalah sikap yang positif terhadap bahasa Indonesia, yang dinyatakan dengan ungkapan "menjungjung bahasa persatuan" itu. Dengan sikap positif itu bahasa Indonesia membuka hubungan saling pengaruh dengan bahasa lain, baik bahasa daerah maupun bahasa asing. Dengan demikian bahasa Indonesia dalam proses perkembangannya menyerap berbagai kata dari bahasa lain. Melalui proses penyerapan itu telah menyebabkan bahasa Indonesia bersalin rupa dari bahasa aslinya (Saadie, 1997/1998:3).

Momentum selanjutnya, pada 1945 bahasa Indonesia ditetapkan dengan UUD 1945 (pasal 36) sebagai bahasa negara. Dalam penjelasan UUD 1945 disebutkan bahwa di daerah-daerah yang mempunyai bahasa sendiri, yang dipelihara oleh rakyatnya dengan baikbaik (misalnya Jawa), bahasa-bahasa itu akan dihormati dan dipelihara juga oleh negara. Bahasa-bahasa itupun merupakan sebagian dari kebudayaan Indonesia yang hidup. Penjelasan itu mengukuhkan apa yang sudah disinggung di atas, yakni saling menerima dan saling melengkapi antara bahasa Indonesia dan bahasa Jawa Baru. Jadi tentu saja bahasa Indonesia pada saat ini sudah tidak lagi sama dengan bahasa Melayu yang menjadi asal-usulnya.

\section{Sejarah Perkembangan Bahasa Jawa Baru}

Bahasa Jawa Baru merupakan bahasa yang dimiliki oleh suku Jawa yang pada dewasa ini diketahui hidup di propinsi Jawa Timur, Jawa Tengah, dan DIY. Di Jawa Tengah pada abad ke-8 hingga ke-12 dan di Jawa Timur abad ke-12 sampai ke-15 tercatat sebagai daerah kekuasaan kerajaan-kerajaan besar seperti Mataram-Kuna, Kediri, Singasari, hingga Majapahit. Kerajaan-kerajaan itu banyak mengembangkan agama dan kebudayaan Hindu, di samping agama dan kebudayaan Budha (Koentjaraningrat, 1990: 23). Kebudayaan dari agama Hindu dan Budha di antaranya meninggalkan warisan berupa candicandi yang megah, antara lain Borobudur dan Prambanan.

Bahasa Jawa diketahui berkembang dari bahasa Jawa Kuna yang banyak dipergunakan bersama pengembangan agama dan kebudayaan Hindu dan Budha tersebut. Dalam bahasa Jawa Kuna ini pengaruh bahasa Sansekerta masih tampak signifikan. Zoetmulder (1983: 10) menekankan bahwa pengaruh India dalam bidang linguistik (Jawa Kuna), pertama-tama dan bahkan hampir eksklusif, disebabkan karena pengaruh dari bahasa Sansekerta.

Menurut Zoetmulder (1983: 11-12) kategori-kategori linguistik yang merangkum kata-kata pinjaman dari Sansekerta, hampir semuanya bersifat kata-kata benda dan katakata sifat yang tidak dideklinasikan atau dalam bentuk lingga. Di antara kata-kata yang berupa kata kerja tidak dijumpai yang dikonyugasikan (kecuali kata astu dan âsit). Kata-kata Sansekerta diserap dan diperlakukan sebagai bahasa Nusantara, yakni diperlakukan sebagai kata dasar bahasa Jawa Kuna yang sering dilengkapi dengan afiksasi bahasa Jawa Kuna. Kata Sansekerta uttama yang berarti 'baik sekali' dibentuk menjadi kata benda abstrak dengan menambah imbuhan bahasa Jawa Kuna $k a-$-an, sehingga menjadi kottaman. Dari kata Sansekerta yatna diberi prefiks Jawa Kuna $\mathrm{ka}$ dan sufiks -na menjadi kata dasar sekunder kayatna, lalu diberi konfiks-in--aken, sehingga 
menjadi kinayatnaken. Bahkan kata-kata yang dalam bahasa Sansekerta telah mempunyai arti pasif, misalnya pariwrta ('dilingkungi'), diperlakukan sebagai kata dasar netral, sehingga sering diberi prefiks dalam bahasa Jawa Kuna $a$ - yang berarti aktif, menjadi amariwrta. Di samping itu juga dibentuk menjadi pasif lagi dengan menambah infiks pasif bahasa Jawa Kuna -in-, sehingga menjadi pinariwrta, dan sebagainya.

Menurut Zoetmulder (1983: 14), proses penyerapan dari Sansekerta, sebagiannya dikarenakan mode dan gengsi akibat sikap menjunjung tinggi sastra Sansekerta, karena dalam beberapa hal bahasa Jawa Kuna sudah memadahi dan tidak ada alasan untuk mengadakan perubahan.

Berdasarkan dokumen tertulis bahasa Jawa Baru ada sejak jaman karya sastra Jawa Surakarta Awal pada tahun 1778 Masehi (Poerbatjaraka 1957: 128). Kata "baru" di sini sama sekali tidak untuk menyatakan 'baru sama sekali', karena hal itu mustahil terjadi dalam perkembangan bahasa. Sejumlah proses kebahasaan dari Jawa Kuna ke Jawa Baru masih dapat bertahan dalam rangka tertentu. Misalnya dalam proses afiksasi, dalam bahasa Jawa Baru masih sering terdengar kata yang berprefiks $a$ sebagai kata kerja aktif, masih ada infiks -inyang berarti pasif, dan sebagainya.

\section{KOSA KATA BAHASA INDONESIA DARI BAHASA SANSEKERTA}

Proses penyerapan kosa kata dari bahasa Sansekerta ke bahasa Indonesia terjadi sebagai berikut.

\section{Tanpa Mengalami Perubahan baik Bunyi, Bentuk Kata, maupun Arti.}

Dalam bahasa Indonesia proses ini terjadi pada kata seperti mitra 'teman', anunasika 'anuswara', durjana 'orang jahat', nara 'orang', aneka 'banyak; berbagai macam; berjenisjenis', putra 'anak laki-laki raja, anak kandung, anak laki-laki, khusus (untuk) lakilaki', dsb. Kata mitra 'teman' berasal dari kata benda neutrum mitra 'teman', kata anunasika berasal dari kata benda neutrum anunasika 'anuswara', kata durjana 'orang jahat' berasal dari kata benda masculinum durjana 'orang jahat', kata nara 'orang', berasal dari kata benda masculinum nara 'orang'. Kata aneka berasal dari kata sifat aneka yang berarti 'beberapa'. Kata putra dalam bahasa Indonesia berasal dari kata benda masculinum putra 'anak laki-laki'.

Contoh lain ialah pada kata majemuk seperti pariwara yang berarti 'iklan yang berupa berita (bukan gambar atau poster); reklane; pemberitaan di (koran dan sebagainya); pengumuman, pengiring; pengikut'. Kata itu dalam bahasa Sanskerta dari prefiks pari 'mengelilingi' dan kata sifat vara 'terbaik, paling baik'.

\section{Mengalami Perubahan Bunyi, tetapi tanpa Mengalami Perubahan Bentuk Kata dan Perubahan Arti.}

Proses penyerapan dari Bahasa Sansekerta ke Bahasa Indonesia, sebagiannya mengalami perubahan bunyi, tetapi tanpa mengalami perubahan bentuk kata dan perubahan arti. Hal ini terjadi antara lain pada sebagian kata dari bahasa Sansekerta yang menggunakan vokal atau semi vokal $r, l, v$ atau $y$. Misalnya pada kata graha 'rumah', pertiwi 'bumi', resi 'pendeta', dsb. Kata graha 'rumah' berasal dari kata benda neutrum grha 'rumah'. Kata pertiwi dari kata benda feminum prthivē 'bumi'. Kata resi 'pendeta' berasal dari kata benda masculinum rsi 'pendeta'. Pada kata grha, prthivi, dan rsi tersebut terjadi karena dalam bahasa Sansekerta terdapat semi vokal $r$ lingual, sedang dalam bahasa Indonesia tidak, sehingga diperlukan vokal lain di antara dua konsonan pada suku yang bersangkutan.

Contoh lain adalah kata surga 'tempat mulia yang menjadi tujuan manusia setelah mati'. Kata surga berasal dari kata benda masculinum svarga. Perubahan bunyi wa menjadi $o$ seperti ini bisa dibandingkan dengan kata mangrwa (Jawa Kuna) menjadi mangro (Jawa Baru) 'mendua', atau sattva (Sansekerta: kata benda neutrum) menjadi sato (Jawa Baru).

Contoh pada kata majemuk antara lain pada kata anumerta 'gelar, pangkat, dsb. yang diberikan sesudah orangnya meninggal dunia'. 
Kata itu berasal dari prefiks anu 'menurut, setelah, mengikuti' dan kata sifat mrta 'mati'. Perubahan yang terjadi adalah pada kata $m r t a$ menjadi merta

Contoh lain yang hanya mengalami perubahan bunyi, misalnya pada kata siswa 'murid'. Kata siswa berasal dari kata benda masculinum çisya yang berarti 'murid'. Ada kemungkinan Bahasa Indonesia menerima kata-kata di atas setelah melalui bahasa daerah lain, misalnya dari bahasa Jawa (akan dijelaskan lagi di bawah).

\section{Mengalami Perubahan Bunyi, Mengalami Pergeseran Arti, Tanpa Mengalami Perubahan Bentuk Kata.}

Proses penyerapan dengan mengalami perubahan bunyi, mengalami pergeseran arti, tetapi tanpa mengalami perubahan bentuk kata terjadi seperti pada kata negara 'organisasi di suatu wilayah yang mempunyai kekuasaan tertinggi yang sah dan ditaati oleh rakyat; kelompok sosial yang menduduki wilayah atau daerah tertentu yang diorganisasi di bawah lembaga politik dan pemerintah yang efektif, mempunyai politik berdaulat sehingga berhak menentukan tujuan nasionalnya'. Kata negara berasal dari kata benda neutrum nagara, semula berarti 'kota'. Agaknya bahasa Indonesia mendapat kata negara setelah melalui bahasa Melayu atau bahasa Jawa Baru, atau bahasa lainnya (dalam Bahasa Jawa Baru akan dijelaskan di bawah).

\section{Mengalami Pergeseran Bunyi ke Konsonan Lain yang Homorgan, Tanpa Perubahan Bentuk Kata dan Arti.}

Proses penyerapan yang lain ialah mengalami pergeseran bunyi ke konsonan lain yang homorgan, tanpa perubahan bentuk kata dan arti. Hal ini terjadi antara lain pada katakata bahasa Sansekerta yang menggunakan konsonan beraspiran, seperti ph, th, kh, ch, dsb. Konsonan beraspiran dalam bahasa Indonesia tidak ada sehingga bergeser pada konsonan yang homorgan tanpa aspiran. Contoh pada kata prthivi, bunyi th bergeser menjadi t. Sedang bunyi $v$ dalam bahasa Sansekerta sama dengan bunyi w dalam bahasa Indonesia, jadi terutama berbeda dalam simbol bunyi saja.

Pergeseran pada konsonan yang homorgan ini juga terjadi pada kata bayu 'angin'. Kata ini berasal dari kata benda masculinum vayu 'angin'. Perubahan $v$ menjadi $b$ ini merupakan perubahan yang terjadi karena lira-liru (silih berganti) bunyi yang homorgan, dalam hal ini bunyi labial.

Contoh lain pada kata suci yang berarti 'bersih (dalam arti keagamaan); tidak berdosa; tidak bercela; tidak bernoda'. Kata suci dalam bahasa Indonesia itu berasal dari kata sifat çuci 'bersih' dalam bahasa Sansekerta, dengan bunyi ç (desis palatal).

Contoh lainnya lagi ialah pada kata wisata atau kata majemuk pariwisata yang berarti 'yang berhubungan dengan perjalanan untuk rekreasi; pelancongan; turisme'. Kata itu dalam bahasa Sansekerta dari prefiks pari 'mengelilingi' dan kata viçata 'ia masuk'. Kata viçata dari urat kata kerja kelas VI viç 'masuk' dan berkonjugasi untuk persona atau pelaku orang ketiga singularis - $t a$ 'ia', sedangkan bunyi $a$ di belakang urat kata kerja viç merupakan pembentuk pangkal presens.

\section{Dengan Perubahan Bunyi dari Vokal Panjang Menjadi Vokal Pendek, Tanpa Perubahan Bentuk Kata dan Arti.}

Proses perubahan bunyi dari vokal panjang menjadi vokal pendek, tanpa perubahan bentuk kata dan arti terjadi seperti pada kata warta 'berita, kabar', praja 'kota, negeri'. Kata warta berasal dari kata benda feminum vārtā 'kabar'. Kata praja berasal dari kata benda feminum prajā yang berarti rakyat.

Contoh lain yakni kata majemuk yang menggunakan kata purna 'penuh; selesai'. Purnabakti 'pensiun (setelah berakhir masa bakti)'. Purnakarya 'berkenaan dengan keadaan atau kedudukan setelah berdinas; berkenaan dengan keadaan atau kedudukan pensiun'. Kata purna berasal dari pürna yang merupakan bentuk kausatif pasif yang berarti 'terisi' yakni dari urat kata kerja kelas X $p r$ 'mengisi'; atau dari bentuk perfect passive participle yang berarti 'penuh'. Kata purnabakti berasal dari 
pūrna 'terisi' dan kata benda feminum bhakti 'kebaktian, hal bakti'. Kata purnakarya berasal dari bahasa Sanskerta pūrna 'terisi' dan kata benda neutrum kārya 'pekerjaan'.

Contoh lainnya lagi pada kata karya 'pekerjaan'. Kosa kata bahasa Indonesia seperti hastakarya yang berarti 'kerajinan tangan', lokakarya yang berarti 'pertemuan antara para ahli (pakar) untuk membicarakan masalah praktis atau yang bersangkutan dengan pelaksanaan di bidang keahliannya; sanggar kerja'. Kata hastakarya 'kerajinan tangan' berasal dari kata benda masculinum hasta 'tangan' dan kata benda neutrum kārya 'pekerjaan'. Kata lokakarya berasal dari kata benda masculinum loka 'dunia, rakyat, tempat' dan kata benda neutrum kārya 'pekerjaan' dalam bahasa Sansekerta.

6. Dengan Perubahan Bunyi dari Konsonan Rangkap Menjadi Konsonan Tunggal, Tanpa Perubahan Bentuk Kata dan Arti.

Proses penyerapan dengan perubahan bunyi dari konsonan rangkap menjadi konsonan tunggal, tanpa perubahan bentuk kata dan arti, terjadi seperti pada kata wisida 'peresmian' atau 'pelantikan'. Kata wisuda dalam bahasa Indonesia berasal dari bahas Sansekerta, yakni dari prefiks vi- dan kata sifat çuddha 'bersih'. Dari contoh itu bunyi $d d h$ pada kata çuddha bahasa Sansekerta diserap menjadi bunyi $\mathrm{d}$ (konsonan tunggal) pada kata wisuda dalam bahasa Indonesia.

\section{Dengan Penambahan Bunyi dari Kata Dasar Bahasa Sansekerta, Tanpa Mengalami Perubahan Bentuk Kata, dan Tanpa Mengalami Perubahan Arti.}

Proses penyerapn dengan penambahan bunyi dari kata dasar bahasa Sansekerta, tanpa mengalami perubahan bentuk kata, dan tanpa mengalami perubahan arti, seperti pada kata gajah 'gajah'. Kata gajah berasal dari bahasa Sansekerta, yakni dari kata dasar kata benda masculinum gaja 'gajah'. Dalam kasus nominatif (berfungsi sebagai subyek atau berdiri sendiri) singularis gaja mestinya berdeklinasi menjadi gajas, namun karena berdiri sendiri, terkena hukum bunyi $s$ berubah menjadi $h$, sehingga menjadi gajah. Agaknya bahasa Indonesia menyerap dalam bentuknya pada kasus nominatif singularis yang berdiri sendiri itu sehingga kata gaja menjadi gajah.

\section{Dengan Penghilangan Bunyi dari Kata Dasar Bahasa Sansekerta, Tanpa Mengalami Perubahan Bentuk Kata, dan Tanpa Mengalami Perubahan Arti.}

Proses penyerapan dengan penghilangan bunyi dari kata dasar bahasa Sansekerta, tanpa mengalami perubahan bentuk kata, dan tanpa mengalami perubahan arti, terjadi seperti pada kata karma 'karma, buah perbuatan'. Kata karma berasal dari bahasa Sansekerta, yakni dari kata dasar kata benda neutrum karman 'karma'. Dalam kasus nominatif (sebagai subyek atau berdiri sendiri) singularis, atau dalam kasus vokatif (panggilan atau seruan) singularis, atau sebagai akkusatif (obyek) singularis, kata karman berdeklinasi menjadi karma. Agaknya bahasa Indonesia menyerap kata karma dalam kasus-kasus tersebut.

Di bawah ini beberapa kosa kata bahasa Indonesia yang diserap dari bahasa Sansekerta. 


\begin{tabular}{|c|c|}
\hline Bahasa Indonesia & Bahasa Sansekerta \\
\hline $\begin{array}{l}\text { dewa: 1. roh yang diangan-angankan sebagai } \\
\text { manusia yang berkuasa atas alam dan } \\
\text { manusia; } 2 \text {. orang atau sesuatu yang sangat } \\
\text { dipuja-puja }\end{array}$ & kata benda masculinum deva 'dewa' \\
\hline $\begin{array}{l}\text { kalpataru: 1. pohon kehidupan yang penuh } \\
\text { pengharapan; pohon penghidupan; } 2 \text {. } \\
\text { penghargaan pemerintah yang diberika } \\
\text { kepada orang atau kelompok yang telah } \\
\text { berjasa dalam memelihara kelestarian } \\
\text { lingkungan hidup }\end{array}$ & $\begin{array}{l}\text { kalpataru dari urat kata kerja klp yang } \\
\text { mempunyai pangkal presens kalpa } \\
\text { 'berharap, mengharapkan', dan kata benda } \\
\text { masculinum taru 'pohon' }\end{array}$ \\
\hline jagat: bumi; dunia; alam & kata benda masculinum jagat 'dunia' \\
\hline swa: sendiri & dari kata sifat sva 'sendiri' \\
\hline $\begin{array}{l}\text { bumi: 1. planet ketiga dari matahari tempat } \\
\text { manusia hidup; dunia; jagat: } 2 \text {. permukaan } \\
\text { dunia; tanah }\end{array}$ & dari kata benda feminum bhûmi 'tanah' \\
\hline giri: gunung & dari kata benda masculinum giri 'gunung' \\
\hline $\begin{array}{l}\text { Eka: satu; tunggaldwi: duatri: tigacatur: } \\
\text { empatpanca: lima dasa: sepuluh }\end{array}$ & $\begin{array}{l}\text { eka: 'satu'dvi: 'dua'tri: 'tiga'catur: } \\
\text { 'empat'pañca: 'lima'daça: 'sepuluh' }\end{array}$ \\
\hline $\begin{array}{l}\text { dosa: 1. perbuatan yang melanggar hukum } \\
\text { Tuhan atau agama; 2. perbuatan salah } \\
\text { seperti (terhadap orang tua, adat, negara) }\end{array}$ & dari kata sifat dosa 'dosa' \\
\hline $\begin{array}{l}\text { masa: } 1 \text {. waktu; ketika; saat; } 2 \text {. jangka waktu } \\
\text { yang agak lama terjadinya suatu peristiwa } \\
\text { penting }\end{array}$ & $\begin{array}{l}\text { dari kata benda masculinum mâsa 'waktu satu } \\
\text { bulan' }\end{array}$ \\
\hline $\begin{array}{l}\text { bupati: 1. (jabatan, sebutan) kepala daerah } \\
\text { kabupaten (daerah tingkat II); 2. pegawai } \\
\text { istana tertinggi }\end{array}$ & dari kata benda masculinum bhûpati 'raja' \\
\hline $\begin{array}{l}\text { guru: orang yang pekerjaannya (mata } \\
\text { pencahariannya, profesinya)mengajar }\end{array}$ & dari kata benda masculinum guru 'guru' \\
\hline $\begin{array}{l}\text { karya: 1. kerja; pekerjaan; 2. (hasil) } \\
\text { perbuatan; buatan; ciptaan (terutama hasil } \\
\text { karangan) }\end{array}$ & dari kata benda neutrum kârya 'pekerjaan' \\
\hline $\begin{array}{l}\text { karma: 1. perbuatan manusia hidup di dunia; } \\
\text { 2. hukum sebab dan akibat }\end{array}$ & dari kata benda neutrum karman 'perbuatan' \\
\hline Usadha: 1 . obat; 2 . ilmu pengobatan & dari kata benda neutrum âusadha 'obat' \\
\hline darma: kewajiban; tugas hidup; kebajikan & $\begin{array}{l}\text { dari kata benda masculinum dharma } \\
\text { 'kebajikan, kewajiban, kebaikan' }\end{array}$ \\
\hline
\end{tabular}




\begin{tabular}{|c|c|}
\hline $\begin{array}{l}\text { putri: } 1 \text {. anak perempuan raja; } 2 \text {. perempuan; } \\
\text { wanita }\end{array}$ & $\begin{array}{l}\text { dari kata benda feminum putrî 'anak } \\
\text { perempuan' }\end{array}$ \\
\hline kala: waktu; ketika, masa & dari kata benda masculinum kâla 'waktu' \\
\hline samudra: laut; lautan & dari kata benda masculinum samudra 'laut' \\
\hline Grahita: mengerti; mengetahui & dari kata sifat grhîta 'tercapai' \\
\hline tuna: rugi & dari kata sifat tuna 'rugi' \\
\hline gita : nyanyian' & dari kata benda neutrum gîta 'nyanyian' \\
\hline mega: awan & dari kata benda masculinum megha 'awan' \\
\hline $\begin{array}{l}\text { wisuda: peresmian atau pelantikan yang } \\
\text { dilakukan dengan upacara khidmat }\end{array}$ & $\begin{array}{l}\text { dari prefiks } v i \text { 'tersebar' dan kata sifat çuddha } \\
\text { 'bersih' }\end{array}$ \\
\hline nara:orang & dari kata benda masculinum nara 'orang' \\
\hline asa: harapan, semangat & dari kata benda feminum âçâ 'pengharapan' \\
\hline $\begin{array}{l}\text { kama: 1. cinta; asmara; nafsu keduniawian; } 2 . \\
\text { Dewa Asmara (menurut mitologi India) }\end{array}$ & $\begin{array}{l}\text { dari kata benda masculinum kâma 'keinginan, } \\
\text { dewa percintaan' }\end{array}$ \\
\hline $\begin{array}{l}\text { hasta: ukuran sepanjang lengan bawah (dari } \\
\text { siku sampai ke ujung jari tengah }=1 / 4 \mathrm{depa} \text { ) }\end{array}$ & dari kata benda masculinum hasta 'tangan' \\
\hline $\begin{array}{l}\text { madu: I cairan yang banyak mengandung zat } \\
\text { gula yang terdapat pada sarang lebah atau } \\
\text { bunga; manis sekali; II } 1 \text {. isteri sah yang lain } \\
\text { dari seorang suami berdasarkan pandangan } \\
\text { istri pertamanya; } 2 \text {. orang yang menjadi } \\
\text { saingan dalam percintaan }\end{array}$ & dari kata benda neutrum madhu 'gula manis' \\
\hline netra:mata & dari kata benda neutrum netra 'mata' \\
\hline pustaka: 1. kitab; buku; 2. buku primbon & $\begin{array}{l}\text { dari kata benda neutrum pustaka 'naskah, } \\
\text { buku' }\end{array}$ \\
\hline jaya: selalu berhasil; sukses; hebat & $\begin{array}{l}\text { dari kata jaya 'menang' merupakan bentuk } \\
\text { pangkal presens dari urat kata kerja } j i \\
\text { 'menang' }\end{array}$ \\
\hline $\begin{array}{l}\text { dana: } 1 \text {. uang yang disediakan untuk suatu } \\
\text { keperluan; } 2 \text {. pemberian; hadiah; derma }\end{array}$ & $\begin{array}{l}\text { dari kata benda neutrum dhana 'uang, } \\
\text { kekayaan' }\end{array}$ \\
\hline $\begin{array}{l}\text { bakti: } 1 \text {. tunduk dan hormat; perbuatan yang } \\
\text { m e n y a takan s et i a ; } 2 . \text { s e t i a } \\
\text { memperhambakandiri }\end{array}$ & dari kata benda feminum bhakti 'kebaktian' \\
\hline
\end{tabular}




\begin{tabular}{|l|l|}
\hline $\begin{array}{c}\text { surga: 1. alam akhirat yang membahagiakan } \\
\text { roh manusia hendak tingal di dalamnya } \\
\text { (dalam keabadian); 2. kayangan tempat } \\
\text { kediaman batara Guru (Siwa) }\end{array}$ & dari kata benda masculinum svarga 'surga' \\
\hline puspa: bunga & dari kata benda neutrum puspa 'bunga' \\
\hline Busana: pakaian & dari kata benda neutrum bhûsana 'perhiasan' \\
\hline
\end{tabular}

\section{E. KOSA KATA BAHASA JAWA BARU DARI BAHASA SANSEKERTA}

Di atas telah disinggung bahwa proses penyerapan kosa kata dari bahasa Sansekerta ke bahasa Indonesia dengan ke bahasa Jawa baru sebagiannya sama. Hal ini terjadi karena banyak hal yang bertautan dalam proses sejarah perkembangan kedua bahasa (bahasa indonesia dan bahasa Jawa Baru). Oleh karena itu tidak berlebihan bila uraian proses penyerapan kosa kata bahasa Sansekerta ke bahasa Jawa Baru di bawah ini sebagiannya sama dengan proses penyerapan dari bahasa Sansekerta ke bahasa Indonesia. Proses penyerapan kosa kata bahasa Sansekerta ke dalam bahasa Jawa Baru sebagai berikut.

\section{Tanpa Mengalami Perubahan Baik Bunyi, Bentuk Kata, Maupun Arti.}

Proses penyerapan kosa kata bahasa Sansekerta ke bahasa Jawa baru, sebagiannya tanpa mengalami perubahan baik bunyi, bentuk kata, maupun arti. Dalam bahasa Jawa Baru proses ini terjadi pada kata seperti mitra 'teman', durjana 'orang jahat', nara 'orang', putra 'anak laki-laki raja, anak kandung, anak laki-laki', dsb. Kata mitra 'teman' berasal dari kata benda neutrum mitra 'teman'. Kata durjana 'orang jahat' berasal dari kata benda masculinum durjana 'orang jahat'. Kata nara 'orang', berasal dari kata benda masculinum nara 'orang'. Kata putra dalam bahasa Jawa Baru berasal dari kata benda masculinum putra 'anak laki-laki'.

Contoh lain ialah pada kata seperti kata guru 'guru' berasal dari kata benda masculinum guru 'guru'. Kata giri 'gunung' berasal dari kata benda masculinum giri 'gunung'. Kata bilangan $d w i$ 'dua', tri 'tiga, catur 'empat' berasal dari kata bilangan $d w i$ 'dua', tri 'tiga', catur 'empat'.
Contoh lain dari Sansekerta seperti pada kata dina 'hari' berasal dari kata benda neurum dina 'hari'. Kata dewa 'dewa' dari kata benda masculinum deva 'dewa'. Kata dosa 'dosa' berasal dari kata sifat dosa 'dosa'. Kata pustaka 'buku, naskah' berasal dari kata benda neutrum pustaka 'buku, naskah'.

\section{Mengalami Perubahan Bunyi, tetapi Tanpa Mengalami Perubahan Bentuk Kata dan Perubahan Arti.}

Penyerapan dengan perubahan bunyi, tetapi tanpa mengalami perubahan bentuk kata dan perubahan arti antara lain terjadi pada sebagian kata dari bahasa Sansekerta yang menggunakan vokal atau semi vokal $r, l, v$ atau $y$. Misalnya pada kata pertiwi 'bumi', resi 'pendeta', griya 'rumah', dsb. Kata pertiwi berasal dari kata benda feminum prthivī 'bumi'. Kata resi 'pendeta' berasal dari kata benda masculinum rsi 'pendeta'. Pada kata prthivi, dan $r s i$ tersebut terjadi karena dalam bahasa Sansekerta terdapat semi vokal $r$ lingual, sedang dalam bahasa Jawa Baru tidak, sehingga diperlukan vokal lain di antara dua konsonan pada suku yang bersangkutan. Pada kata griya, sedikit berbeda dengan proses dalam bahasa Indonesia, karena dalam bahasa Indonesia menjadi graha. Kata griya dalam bahasa Jawa Baru juga berasal dari kata benda neutrum grha 'rumah'. Dalam bahasa Jawa Baru bunyi $h$ sering lira-liru (silih berganti) dengan bunyi $y$. Sebagai contoh kata kaliyan sering juga ditulis kalihan. Agaknya proses griya itu dilalui dengan hilangnya aspiran $h$, sehingga menjadi gri-a dan akhirnya muncul bunyi $y$ sebagai bunyi pelancar antara bunyi $i \operatorname{dan} a$. 
Contoh lain yakni pada kata suwarga 'tempat mulia yang menjadi tujuan manusia setelah mati'. Kata suwarga berasal dari kata benda masculinum svarga 'surga'. Semi vokal $v$ (w) dalam bahasa Jawa Baru kadang dimunculkan kadang tidak, sehingga bentuk suwarga sering juga diucapkan swarga. Dalam bentuk suwarga diperlukan sisipan bunyi $u$ sebagai bunyi pelancar antara konsonan $s$ dengan $w$.

Contoh lain yang mengalami perubahan bunyi, misalnya pada kata siswa 'murid'. Kata siswa berasal dari kata benda masculinum çisya yang berarti 'siswa'. Dalam bahasa Jawa Baru antara $y$ dengan $w$ juga sering lira-liru (silih berganti). Sebagai contoh dalam bahasa Jawa Baru, kata kalawan atau klawan dengan kalayan atau klayan yang sama-sama berarti 'dengan'. Kata jawa Baru yang juga liraliru, syeneh dengan sweneh atau saweneh yang berarti 'selain, sebagian lainnya', yang dalam bentuk yang agak jauh menjadi sanes atau senes. Kata keliwatan lira-liru dengan kata kelayatan atau kelayadan, dsb.

\section{Mengalami Perubahan Bunyi, Mengalami Pergeseran Arti, Tanpa Mengalami Perubahan Bentuk Kata.}

Penyerapan dengan perubahan bunyi, pergeseran arti, tanpa mengalami perubahan bentuk kata terjadi seperti pada kata negara 'organisasi di suatu wilayah yang mempunyai kekuasaan tertinggi yang sah dan ditaati oleh rakyat; kelompok sosial yang menduduki wilayah atau daerah tertentu yang diorganisasi di bawah lembaga politik dan pemerintah yang efektif, mempunyai politik berdaulat sehingga berhak menentukan tujuan nasionalnya'. Kata negara berasal dari kata benda neutrum nagara, semula berarti 'kota'. Dalam bahasa Jawa Baru, pergantian bunyi secara lira-liru (silih berganti) antara bunyi $a$ dan $e$ pada suku pertama dari kata yang terdiri atas tiga suku sering terjadi, misalnya kata karana dengan kerana atau krana, kata gapura dengan gepura, kata sapata dengan sepata, dsb. Bahkan dalam bentuk kata ulang suku depan (dwipurwa), banyak yang salin swara (berubah bunyi), misalnya kata jejaka dari jajaka, kata tetakon dari tatakon, kata pepadhang dari papadhang, kata sesanggan dari sasanggan, kata sesulih dari susulih, dsb.

\section{Mengalami Pergeseran Bunyi ke Konsonan Lain yang Homorgan, Tanpa Perubahan Bentuk Kata dan Arti.}

Proses penyerapan yang mengalami pergeseran bunyi ke konsonan lain yang homorgan, tanpa perubahan bentuk kata dan arti antara lain terjadi pada kata-kata bahasa Sansekerta yang menggunakan konsonan beraspiran, seperti th, kh, ch, dsb. Konsonan beraspiran dalam bahasa Jawa Baru tidak ada sehingga bergeser pada konsonan yang homorgan tanpa aspiran. Contoh pada kata prthivi, bunyi th bergeser menjadi t. Sedang bunyi $v$ dalam bahasa Sansekerta sama dengan bunyi w dalam bahasa Jawa Baru, jadi terutama berbeda dalam simbol bunyi saja.

Contoh lain adalah pada kata bujana atau bojana 'makanan' dari kata benda neutrum bhüjana atau bhojana 'makanan'. Kata mega 'awan' dari kata benda masculinum megha 'awan', Kata madu 'madu'dari kata benda neutrum madhu 'madu, gula manis'.

Hal yang hampir sama juga terjadi pada kata bayu 'angin'. Kata ini berasal dari kata benda masculinum vayu (dibaca wayu) 'angin'. Antara bunyi w dengan b sama-sama dihasilkan oleh labium (konsonan labial). Dalam bahasa Jawa bunyi $w$ dengan $b$ juga sering lira-liru. Misalnya pada kata wasuh dengan basuh 'basuh', kata abot dengan awrat 'berat', kata mbobot dengan wawrat 'hamil', kata obah dengan owah 'bergerak, berubah', kata imbuh dengan wuwuh 'tambah', dsb.

Contoh lain pada kata suci yang berarti 'bersih (dalam arti keagamaan); tidak berdosa; tidak bercela; tidak bernoda'. Kata suci dalam bahasa Jawa Baru itu berasal dari kata sifat çuci 'bersih' dalam bahasa Sansekerta. Dalam bahasa Jawa baru tidak ada $c$ palatal sehingga menjadi $s$ dental. 
5. Mengalami Perubahan Bunyi dari Vokal Panjang Menjadi Vokal Pendek, Tanpa Perubahan Bentuk Kata dan Arti.

Proses penyerapan yang mengalami perubahan bunyi dari vokal panjang menjadi vokal pendek, tanpa perubahan bentuk kata dan arti terjadi seperti pada kata warta 'berita, kabar', kata segara 'laut', dsb. Kata warta berasal dari kata benda feminum vārtā 'kabar'. Kata sagara atau segara 'laut' dari kata benda masculinum sāgara 'laut'. Kata dana 'hadiah, pemberian' dari kata benda neutrum dāna 'hadiah, pemberian'.

6. Dengan Perubahan Bunyi dari Konsonan Rangkap Menjadi Konsonan Tunggal, Tanpa Perubahan Bentuk Kata dan Arti.

Proses penyerapan dengan perubahan bunyi dari konsonan rangkap menjadi konsonan tunggal, tanpa perubahan bentuk kata dan arti, terjadi seperti pada kata wisuda 'peresmian' atau 'pelantikan'. Kata wisuda dalam bahasa Indonesia berasal dari bahas Sansekerta, yakni dari prefiks vi- dan kata sifat çuddha 'bersih'. Dari contoh itu bunyi $d d h$ pada kata çuddha bahasa Sansekerta diserap menjadi bunyi $d$ (konsonan tunggal) pada kata wisuda dalam bahasa Jawa Baru.

\section{Dengan Penambahan Bunyi dari Kata} Dasar Bahasa Sansekerta, Tanpa Mengalami Perubahan Bentuk Kata, dan Tanpa mengalami perubahan arti,

Proses penyerapan dengan penambahan bunyi dari kata dasar bahasa Sansekerta, tanpa mengalami perubahan bentuk kata, dan tanpa mengalami perubahan arti, seperti pada kata gajah 'gajah'. Kata gajah berasal dari bahasa Sansekerta, yakni dari kata dasar kata benda masculinum gaja 'gajah'. Dalam kasus nominatif singularis gaja mestinya berdeklinasi menjadi gajas, namun karena berdiri sendiri, terkena hukum bunyi $s$ berubah menjadi $h$, sehingga menjadi gajah. Agaknya bahasa Jawa Baru menyerap dalam bentuknya pada kasus nominatif singularis yang berdiri sendiri itu sehingga kata gaja menjadigajah .

\section{Dengan Penghilangan Bunyi dari Kata Dasar Bahasa Sansekerta, Tanpa Mengalami Perubahan Bentuk Kata, dan Tanpa Mengalami Perubahan Arti}

Dengan penghilangan bunyi dari kata dasar bahasa Sansekerta, tanpa mengalami perubahan bentuk kata, dan tanpa mengalami perubahan arti, seperti pada kata karma 'karma, buah perbuatan'. Kata karma berasal dari bahasa Sansekerta, yakni dari kata dasar kata benda neutrum karman 'karma'. Dalam kasus nominatif (sebagai subyek atau berdiri sendiri) singularis, atau dalam kasus vokatif (panggilan atau seruan) singularis, atau dalam akkusatif (obyek) singularis, kata karman berdeklinasi menjadi karma. Agaknya bahasa Jawa Baru, seperti dalam bahasa Indonesia, menyerap kata karma dalam kasus-kasus tersebut.

\section{G. PENUTUP}

Bahasa Indonesia dan Jawa Baru dalam perkembangannya menyerap kosa kata dari bahasa Sansekerta. Banyak kosa kata yang sama yang diserap dari bahasa Sansekerta ke dalam bahasa Indonesia dan bahasa Jawa Baru. Bila bahasa Jawa dan bahasa Indonesia saling mempengaruhi, boleh jadi Bahasa Indonesia menyerap kosa kata dari bahasa Sansekerta setelah melalui bahasa Jawa, atau sebaliknya. Namun demikian bila mengacu pada sejarah perkembangannya, sangat memungkinkan bahwa bahasa Indonesia dan Jawa Baru menyerap sumber Sansekerta melalui bahasa Jawa Kuna. Hal ini dimungkinkan karena bahasa Sansekerta telah mati sejak abad ke-10.

Penyerapan kosa kata bahasa Sansekerta, setidak-tidaknya ada delapan proses, yakni: (1) tanpa mengalami perubahan baik bunyi, bentuk kata, maupun arti, (2) mengalami perubahan bunyi, tetapi tanpa mengalami perubahan bentuk kata dan perubahan arti, (3) mengalami perubahan bunyi, mengalami pergeseran arti, tanpa mengalami perubahan bentuk kata, (4) 
mengalami pergeseran bunyi ke konsonan lain yang homorgan, tanpa perubahan bentuk kata dan arti, (5) mengalami perubahan bunyi dari vokal panjang menjadi vokal pendek, tanpa perubahan bentuk kata dan arti, (6) dengan perubahan bunyi dari konsonan rangkap menjadi konsonan tunggal, tanpa perubahan bentuk kata dan arti. (7) mengalami penambahan bunyi dari kata dasar bahasa Sansekerta, tanpa mengalami perubahan bentuk kata, dan tanpa mengalami perubahan arti, dan (8) dengan penghilangan bunyi dari kata dasar bahasa Sansekerta, tanpa mengalami perubahan bentuk kata, dan tanpa mengalami perubahan arti.

Masih terbuka kemungkinan proses yang lain, mengingat tulisan ini bukan hasil dari penelitian secara menyeluruh terhadap semua kosa kata hasil serapan dari bahasa Sansekerta pada bahasa Indonesia dan bahasa Jawa Baru. Oleh karena itu disarankan untuk dilakukan penelitian lebih lanjut.

\section{DAFTAR PUSTAKA}

Koentjaraningrat, 1984. Kebudayaan Jawa, Jakarta: Balai Pustaka

ed., 1990, Manusia dan

Kebudayaan di Indonesia, Jakarta: Djambatan , 1993, Masalah kesukubangsaan dan Integrasi Nasional, Jakarta: UI Press

Macdonell, Arthur A. 1924. A Practical Sanskrit Dictionary. Oxford University Press.

1926. A Sanskrit Grammar For Student. Oxford University Press.

Padmapuspita, Asia. 1974. Bahasa Sanskerta Sebagai Bahasa Bantu. Yogyakarta. Yayasan Penerbitan IKIP Negeri Yogyakarta.

Prawiroatmodjo. S. 1985. Bausastra Jawa Indonesia. Jakarta. Gunung Agung.

Poerbatjaraka. R. Ng. 1957. Kapustakan Jawi. Djakata. Djambatan.
Saadie, Ma'mur dkk. 1997/1998. Bahasa Bantu. Jakarta. Depdikbud.

Soebadio, Haryati.1983. Tatabahasa Sanskerta Ringkas. Jakarta. Djambatan.

Sudharta, Tjok Rai. 1998. Pelajaran Bahasa Sanskerta Tahap Pertama. Surabaya. Paramita

Supardo, Susilo. 2002. "Integrasi Leksikon Bahasa Sansekerta ke dalam Bahasa Indonesia yang Digunakan di dalam Tajuk Rencana Surat Kabar Kedaulatan Rakyat: studi Kasus" Litera, Volume 1 Nomor 2. Yogyakarta. FBS Universitas Negeri Yogyakarta.

Suwito, 1982, Sosiolinguistik, Surakarta: Henary

Zoetmulder. 1983, Kalangwan: Sastra Jawa Kuno Selayang Pandang, Jakarta: Djambatan 